\title{
Potensielle biologiske mekanismer ved psykosesykdommer
}

\author{
Resultater fra genetiske, molekylære og epidemiologiske studier viser at \\ immunrelaterte mekanismer kan spille en rolle ved psykosesykdommer.
}

Schizofreni og bipolar lidelse er komplekse sykdommer med opp mot $80 \%$ arvelighet. Sykdommene debuterer gjerne i ung alder og medfører ofte stort funksjonstap og økt dødelighet. Vi vet lite om de bakenforliggende biologiske sykdomsmekanismene ved alvorlige psykosesykdommer. Tilgjengelige medisiner er kun symptomlindrende og ofte forbundet med bivirkninger som økt risiko for å utvikle metabolsk syndrom.

I min doktorgradsavhandling har jeg undersøkt om endotel- og inflammasjonsmarkører kan være involvert i patogenesen ved psykosesykdommer. Vi fant betydelig øt ekspresjon av et immunrelatert gen (NOTCH4) hos pasienter med bipolar lidelse, sammenliknet med friske kontrollpersoner og pasienter med schizofreni. Proteinet NOTCH4 er involvert i T-cellemediert immunrespons, inflammasjon i vaskulært endotel og i makrofagaktivering. I tillegg har proteinet en regulerende funksjon i utviklingen av sentralnervesystemet.
Videre fant vi at overvekt og høyt blodsukker forbundet med annengenerasjons antipsykotika var sterkt assosiert med økt inflammasjon, spesielt høyere nivåer av Creaktivt protein (CRP). I tillegg viste vi en sammenheng mellom endotel- og inflammasjonsmarkører og hjernemorfologiske forandringer som kan ses hos pasienter med schizofreni.

Disse funnene kan bidra til å øke forståelsen av de bakenforliggende biologiske sykdomsmekanismene ved alvorlige psykosesykdommer. Jeg og mine kolleger ved NORMENT-K.G. Jebsen-senter for psykoseforskning skal nå undersøke andre potensielle immunrelaterte mekanismer som kan være involvert i utviklingen av psykosesykdommer. På sikt er målet med denne forskningen å bidra til utviklingen av nye og bedre medisiner til denne pasientgruppen.

\section{Ingrid Dieset}

ingrid.dieset@medisin.uio.no

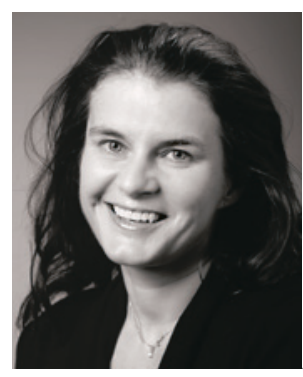

Ingrid Dieset. Foto: Øystein $\mathrm{H}$. Horgmo, Universitetet i Oslo

\section{Disputas}

Ingrid Dieset disputerte for ph.d.-graden ved Universitetet i Oslo 28.11. 2013. Tittelen på avhandlingen er Endothelial and inflammation markers in schizophrenia and bipolar disorder.

\section{Hormonbehandling og symptomer i overgangsalderen}

\author{
Norske kvinner tåler overgangsalderen godt. Allmennlegene er blitt mer \\ restriktive i forskrivning av hormonbehandling, og deres egen holdning \\ til hormonbehandling betyr mye for rådene de gir.
}

Kunnskapsgrunnlaget for hormonbehandling under og etter overgangsalderen ble betydelig endret i 2002, da nye studier viste at behandlingen ikke forebygger hjertesykdom, og at den gir økt risiko for brystkreft. Nye retningslinjer anbefalte en mer restriktiv praksis. Vi har visst lite om i hvilken grad dette har påvirket allmennlegers forskrivning.

I den første delen av min avhandling ble 400 allmennleger spurt om effekter og risiko ved bruk av hormonbehandling samt egne holdninger til behandlingen. Legene var i all hovedsak kjent med kunnskapsgrunnlaget. En vesentlig andel av kvinnelige allmennleger brukte hormonbehandling selv. Legenes holdning til hormonbehandling som mulig medikalisering av en naturlig livsfase var avgjørende for deres behandlingsråd.

I andre del av avhandlingen ble 2229 kvinner spurt annethvert år fra 40-44 års alder til 53-57 år om klimakterielle symptomer, livsstilsfaktorer og bruk av hormonbehandling.
En tredel av kvinnene rapporterte plagsomme hetetokter i løpet av observasjonsperioden. Insidens av hormonbehandling sank signifikant etter 2002, og både insidens og prevalens av hormonbehandling var deretter konstant tross økende symptombyrde ved økende alder. Likevel rapporterte ikke kvinnene dårligere helse. Daglig røyking medførte økt risiko for symptomer og tidligere overgangsalder. Etter avsluttet hormonbehandling kom symptomene tilbake hos de fleste av kvinnene.

Undersøkelsen gir viktig dokumentasjon av klimakteriell symptombelastning og faktorer som kan disponere for økt symptombyrde. Legenes holdning til behandling har betydning for rådene de gir, og klinikeren bør aktivt undersøke kvinnens preferanser når det gjelder leveregler og medikamentell behandling av symptomer.

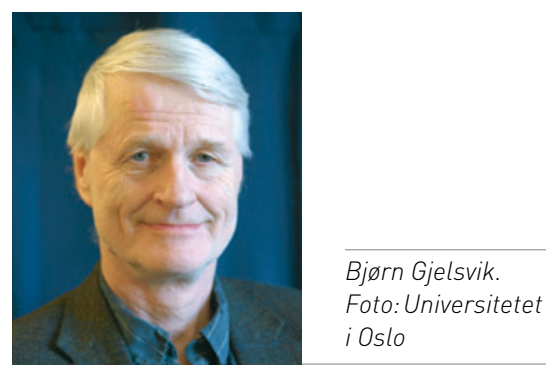

Disputas

Bjørn Gjelsvik disputerte for ph.d.-graden ved Universitetet i Oslo 25.11. 2013. Tittelen på avhandlingen er The menopause. Symptoms, use of hormones and general practitioners' attitudes and advice. Studies of a Norwegian female cohort and Norwegian general practitioners. 